\title{
Exercise-induced non-sustained ventricular tachycardia in patients without significant findings during exercise stress testing - what does it tell us?
}

\author{
(iD)Edin Begić ${ }^{*}$, \\ (i)Amer Iglica ${ }^{2}$, \\ (D)Zijo Begić ${ }^{3}$, \\ (D)Nedim Begić ${ }^{3}$, \\ DAda Đozić', \\ DFaruk Čustović ${ }^{1}$ \\ 'General Hospital "Prim.dr. \\ Abdulah Nakaš", Sarajevo, \\ Bosnia and Herzegovina \\ ${ }^{2}$ Clinic for heart, blood vessels \\ and rheumatism, Clinical \\ Center University of Sarajevo, \\ Sarajevo, Bosnia and \\ Herzegovina \\ ${ }^{3}$ Pediatric Clinic, Clinical \\ Center University of Sarajevo, \\ Sarajevo, Bosnia and \\ Herzegovina
}

\author{
KEYWORDS: coronary artery disease, screening, exercise test. \\ CITATION: Cardiol Croat. 2021;16(1-2):10. | https://doi.org/10.15836/ccar2021.10
}

*ADDRESS FOR CORRESPONDENCE: Edin Begić, General Hospital "Prim.dr. Abdulah Nakaš”, Kranjčevićeva 12, 71000 Sarajevo, Bosnia and Herzegovina. / Phone: +387-61303375 / E-mail: edinbegic90@gmail.com

ORCID: Edin Begić, https://orcid.org/0000-0001-6842-262X • Amer Iglica, https://orcid.org/0000-0002-4677-8489 Zijo Begić, https://orcid.org/0000-0002-1863-5755 • Nedim Begić, https://orcid.org/0000-0001-5964-2305 Ada Đozić, https://orcid.org/0000-0002-2664-810X • Faruk Čustović, https://orcid.org/0000-0001-7254-8858

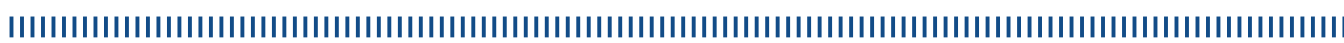

Goal: Indicate the prognostic significance of non-sustained ventricular tachycardia (NSVT) in the recovery phase of stress testing.

Patients and Methods: From total of 584 findings, 14 patients who developed an episode of NSVT (3 beats of ventricular origin and more) in the recovery phase of stress testing (according to the Bruce protocol) were analyzed. Patients who did not have a significant finding during exercise stress testing (without significant ST-segment changes and significant heart rhythm disorders) were included.

Results: After $247 \pm 53$ seconds (4 minutes and 11 seconds) in average patients developed NSVT, and were referred for coronary angiography. Of total number, 4 had a significant finding on coronary angiography; 3 patients had single-vessel coronary disease (one received a stent on right coronary artery (RCA), two on left anterior descending artery (LAD)), and one had triple-vessel coronary disease (received a stent on circumflex artery (CX) and LAD).

Conclusion: The prognostic significance of NSVT is quite unclear, and the origin of NSVT can be ischemic or idiopathic., ${ }^{1,2}$ Regardless, patients with NSVT are candidates for additional evaluation of ischemic heart disease (stress echocardiography, multi-slice computed tomography (MSCT) or invasive coronary angiography).
RECEIVED:

December 8, 2020

ACCEPTED:

December 18, 2020

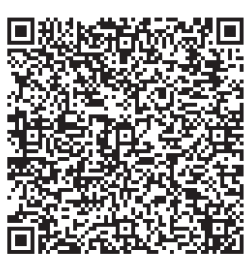

$\square$ Cardiologia Croatica 2021;16(1-2):10.
13. kongres Hrvatskoga kardiološkog društva s međunarodnim sudjelovanjem Virtualni kongres 10. do 13. 12. 2020./ 21. do 24.01.2021.

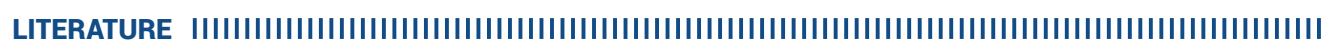

1. Dadkhah S, Dowlatshahi S, Sharain K, Sharain R. Exercise induced non-sustained ventricular tachycardia and indication for invasive management. Clin Med Insights Cardiol. 2011;5:121-6. https://doi.org/10.4137/CMC.S8504

2. Marine JE, Shetty V, Chow GV, Wright JG, Gerstenblith G, Najjar SS, et al. Prevalence and prognostic significance of exercise-induced nonsustained ventricular tachycardia in asymptomatic volunteers: BLSA (Baltimore Longitudinal Study of Aging). J Am Coll Cardiol. 2013 Aug 13;62(7):595-600. https://doi.org/10.1016/j.jacc.2013.05.026 